\title{
ASSESSMENT OF THE STATE OF SOIL'S MICROBIAL COMMUNITY IN CONDITION OF INTENSIVE INFLUENCE OF POLLUTANTS
}

\author{
LYDIA PAVLOVNA STEPANOVA ${ }^{1}$, AZA VALERIEVNA PISAREVA $\otimes^{2}$, VYACHESLAV ANDREEVICH RASKATOV ${ }^{3}$ \\ ${ }^{1}$ Orel State Agrarian University, Russia, 302019, Generala Rodina st., 69, Orel, Russian Federation; e-mail: steplp@yandex.ru \\ ${ }^{2}$ Bauman Moscow State Technical University, 105005, 2-ya Baumanskaya, 5-1, Moscow, 105005, Russian Federation; e-mail: pavpav@bmstu.ru \\ ${ }^{3}$ Russian State Agrarian University - Moscow Timiryazev Agricultural Academy, Timiryazevskaya st., Moscow, 127550, Russian Federation \\ $\bowtie$ Corresponding author
}

Received: 4 December 2019 / Accepted: 12 March 2019

Abstract

Stepanova L.P., Pisareva A.V., Raskatov V.A.: Assessment of the state of soil's microbial community in condition of intensive influence of pollutants. Ekológia (Bratislava), Vol. 40, No. 1, p. 8-15, 2021.

\begin{abstract}
This paper presents the study of toxicological state of the soil. It shows ecological and microbiological properties of the soil mantle in the areas of technological environmental impact and evaluates changes in the number of soil microorganisms as a result of toxic contamination of urban soil at different distances from the Moscow loop highway, and also as a result of dumping aluminum foundry slag in Orel region. Soil-inhabiting invertebrates species composition was evaluated at different soil contamination conditions. It was proven that the state of microbiocenosis changes depending on the intensity and character of the anthropogenic impact. It was established that soil fermentation and microbiological activity changes depending on the value of the cumulative heavy metals' build-up coefficient. Study of interelement ties between the heavy metals concerned showed that they too may have the same anthropogenic origin regardless of their sources of origin. Pollution index indicates medium to high level of soil contamination in explored urban territories where vehicle emission is the main source of pollution, and dangerously high contamination of light-gray soil in the small settlement impacted by a nearby slag disposal site.
\end{abstract}

Key words: microorganisms, urbanozems, invertebrates, mesofauna, heavy metals.

\section{Introduction}

Contamination of soil and plants by heavy metals adversely effects growth and development of plants, water purging properties and food safety (Ksenofontov et al., 2016; Ksenofontov, Goncharenko, 2016). We collected soil samples for further quantification of heavy metal concentration in road-side, industrial, and residential areas of Moscow and Bolshoye Dumchino village (Orel region) to evaluate the spatial variations in heavy metal soil contamination connected to urbanization and local land utilization (Fritz, 2017). Soil carbon sequestration plays an important role in mitigating the anthropogenic increases in atmospheric carbon dioxide concentrations (Kuznetsova et al., 2019).

Biodiversity increases the stability of ecosystem functioning. This is the most frequent pattern in the field of ecosystem functioning, which has been evaluated generally at the community scale (Pershin et al., 2020).

We found the highest content of heavy metals in the soil of the wayside green belts and the lowest at a large distance from the sources of contamination (Ksenofontov et al., 2016). Heavy metal content of all the studied soil samples was positively correlated (Ksenofontov et al., 2017). Heavy metals are chemical elements with density exceeding $5 \mathrm{~g} / \mathrm{cm}^{3}$ and atomic weight of more than $40 \mathrm{~g} / \mathrm{mol}$ (Arinushkina, 1970). Accumulation of heavy metals in the soil increases their mobility because of penetration into deeper layers of soil covering, contamination of vegetation, suppression of biota, and increase of heavy metal content in subsoil waters (Ksenofontov et al., 2016; Ksenofontov, Starostin, 2016).

Territories of large cities contribute significantly to the amount of heavy metals in the environment (Ksenofontov et al., 2016). Metal plants are characterized by an area of maximum concentration of heavy metals with $5 \mathrm{~km}$ radius around the source of contamination and expanded areas of high heavy metals' concentrations reaching 20 to $50 \mathrm{~km}$ from the urban sources of contamination (Ksenofontov et al., 2016). Despite reduction in aerial emissions of industrial metal plants and decrease in the amount of contaminating substances getting into the soil by air, such emissions are reaching high levels especially in the industrial Asian countries, the USA, and Canada (Arkharov et al., 2016).

In the process of urbanization anthropogenic activities bring greater amount of contaminating substances into urban environment thus increasing the concentration of heavy metal contaminants in the soil (Bednova et al., 2018; Stepanova et al., 2020 a,b); Ksenofontov et al., 2016). Studies show obvious correlation between heavy metal content and distance from the

(C) The Author(s) 2021. This is an open access article distributed under the terms of the CC BY-NC-ND license.

https://content.sciendo.com/view/journals/eko/eko-overview.xml 
source of soil contamination on highway shoulders and around slag dumps (Ksenofontov et al., 2017).

The authors suggest the most effective methods of planting trees and shrubs for soil phytoremediation in order to rehabilitate soil covering (Ksenofontov et al., 2017).

Unregulated wastewater discharge and drainage flow from farmlands leads to contamination of rivers, water reservoirs, and irrigated lands (Ksenofontov et al., 2016; Ksenofontov, 2019; Kozodaev et al., 2019a). The expediency of mixing sewage sludge compost with soil and using it in seed plats to grow shrubs, trees, and ornamental plants was proven (Ksenofontov et al., 2016; Ksenofontov, 2018; Ksenofontov, Goncharenko, 2018; Kozodaev et al., 2019b).

It is noteworthy that slag dumps contaminate the environment with heavy metals, which leads to negative ecological consequences for physical and chemical soil properties (Ksenofontov et al., 2017; Stepanova et al., 2019a,c). Heavy metals directly influence the reaction of soil medium because of interaction between heavy metal compounds and water (Novák et al., 2020). In practice, this leads to decrease in $\mathrm{pH}$ because heavy metal compounds are hydrolytically acid (Ksenofontov et al., 2016). Thus, elevation specific land management strategies that improve these SQ indicators need to be emphasized (Abera, Assen, 2019).

Decrease of heavy metals content in soils is connected to their uniform penetration to the depth of 25 to $27 \mathrm{~cm}$ because of increase in infiltration of water and mineralization of organic substance (Ksenofontov et al., 2016). Scientists proved that the main elements contaminating the urbanozem in the investigated roadside territories are $\mathrm{Zn}, \mathrm{Pb}, \mathrm{Cu}, \mathrm{Co}, \mathrm{Cd}$. It should be noted that measures to detoxicate soil must be well thoughtout considering special types of commercial, soil-geographical, geobotanical, and agricultural planning (Ksenofontov et al., 2017). Accelerated soil erosion is a problem resulting from inappropriate land management, which affects both the presence of organic matter and the soil structure. The tool for elimination of negative impacts on soil can be its sustainable use (Stepanova et al., 2020a). This requires the use of an accurate system to improve its condition (Petlušová et al., 2020).

As a result of the succession, ecosystems gradually adapt to various anthropogenically transformed conditions followed by forming specific soils in line with urbanized conditions (Bednova et al., 2018).

Researchers took soil samples at a depth of 0 to $20 \mathrm{~cm}$ in order to evaluate urban soil contamination in Moscow in 2015. They also determined heavy metals, benzopyrene, and petroleum products' content, $\mathrm{pH}$ value of water-salt extract, organic substances' content, amount of dried residue, and major mineral elements $\left(\mathrm{P}_{2} \mathrm{O}_{5}, \mathrm{~K}_{2} \mathrm{O}, \mathrm{NO}_{3}, \mathrm{NH}_{4}\right)$. It is noteworthy that the data obtained is similar to the results of ecological monitoring in 2013. At the same time, they noticed significant alkalinization of urbanozem with deicing chemicals (Stepanova et al., 2020b).

Increase in heavy metal concentration enhances inhibitory effect, which correlates with duration of heavy metals' impact on metabolic processes in soils, microorganisms, plants, animals, and humans (Stepanova et al., 2020a,b). It was proven that actinomycetes-able to act as symbiotes of invertebrates living in soil-are similarly distributed by numerical strength in soil samples. This tightly correlates with food chain ties in microbial community and also with the phenomena of metabiosis and protocooperation in the process of decay of incoming organic substances in soils (Stepanova et al., 2019b,c). Some scientists (Ksenofontov, Goncharenko, 2016) prove that heavy metals' toxicity in soils can be entirely explained by inhibiting many soil enzymes.

Analysis of scientific publications also shows that parameters of biochemical activities of soils and response of organisms living in soils are used as characteristics of soils contaminated with toxic substances. The results of the study were presented in the form of tables that can be used in landscape and environmental practice (Falt'an et al., 2017). It should be noted that it is now becoming very important to monitor the health of the population living in polluted areas, so it is necessary to improve the ecological state of the environment. For example, the population of Vladimir and Orel regions, the influence of environmental factors on the formation of health of the adult population, and the health of school-age children, from the point of view of the annual dynamics of morbidity of the circulatory system and some associated diseases (Stepanova et al., 2019a,b). Factors affecting the state of contaminated territories, in turn, affect human health. The effect of industrial waste and motor vehicle emissions on the geochemical features and environmental sustainability of soil, plants, surface water and the atmosphere in the study area is shown (Stepanova et al., 2019c; Stepanova, Pisareva, 2019). The differential criterion of primary pathology of the circulatory system should be considered as an indicator that integrally reflects the degree of adaptation of the population to environmental conditions and is suitable for constructing short-term prognostic estimates (Trifonova, Shirkin, 2015).

\section{Material and research methods}

The first study object is situated in Bolshoye Dumchino village (Mtsensk district, Orel region, Russia). The village is separated from Moscow by $294 \mathrm{~km}$ and from the town of Orel, the regional center, by $45 \mathrm{~km}$. This territory belongs to the Podmokrinskoye rural settlement with population of 1200 . Mtsensk district is situated in the north-eastern part of the Orel region and occupies more than 1.7 thousand square $\mathrm{km}$. It borders Zalegoschensky, Novosilsky, and Korsakovsky districts of Orel region, and Chernsky district of Tula region.

Soils of Mtsensk district are represented mainly by dark gray forest soils and gray forest soils. The district has moderately continental climate. The district is characterized by moderate winter temperatures (between -3 and $-15^{\circ} \mathrm{C}$ ) and moderate summer temperatures (between 14 and $25^{\circ} \mathrm{C}$ ). Winter lasts for approximately 5 months. Summer is rather warm and long, it lasts for approximately 4 months. Average annual precipitation in Mtsensk district $546 \mathrm{~mm}$. Average air humidity in cold time of year is $85 \%$, in summer-more than $70 \%$. Wind speed and pattern influences the dispersal of polluting substances coming from different sources differently. Average monthly wind speeds reach more than $4 \mathrm{~m} / \mathrm{sec}$.

Soil and plant degradation comes from slag dumps of the industrial enterprise «Mcenskij Litejnyj Zavod» (Mtsensk).

Continuous monitoring sites (CMSs) at different distances from a slug dump $(50,150,300,450 \mathrm{~m})$ were chosen as a study object. The soil was medium-power gray forest soil, medium 
clay-and-sand loess soil, medium-humic typical gley soil.

CMSs in the immediate proximity of M-2 highway were chosen for ecological evaluation of the extent of soil pollution. This territory stretches along the village and field protected from the road by roadside trees. Test plots have low power clay-and-sand gray forest soil. Control sections were made in CMSs at the nature reserve near the pond, at the tilled area near the park, and at the car-park.

The second study object is Moscow, the capital of Russia, city with federal status. It is situated in the center of the East European Plain, in-between rivers Oka and Volga, at the junction of Smolensk-Moscow Upland (in the West), Moscow-Oka Upland (in the East), and Meshchera Lowlands (in the South-East). The territory of the city is $2561.5 \mathrm{~km}^{2}$ (as of 2019), approximately $900 \mathrm{~km}^{2}$ is situated inside the Moscow ring highway.

Population of Moscow is $12,615,279$. It is worth noting that Moscow is one of the ten most populous cities in the world and the largest Russian-speaking city in the world. It has GPS coordinates 55.753215, 37.622504. The Moscow city has moderately continental climate with distinct seasons. Winter (up to 4 months a year) can have short periods of strong frosts (up to $-25 \ldots-30^{\circ} \mathrm{C}$ ). Thaws (between -5 and $-10^{\circ} \mathrm{C}$ ) are often possible in December and January with temperatures going to $0{ }^{\circ} \mathrm{C}$ and higher (between 5 and $9^{\circ} \mathrm{C}$ ). Summer (temperatures higher than $20-30^{\circ} \mathrm{C}$ ) lasts around 3.5 months. The average yearly wind speed is $2.3 \mathrm{~m} / \mathrm{sec}$. The average yearly air humidity is $77 \%$. In recent years, the yearly amount of precipitation in Moscow is $700 \mathrm{~mm}$. Most of it comes in summer.

Initially, Moscow soils were soddy podzolic. They were transformed in the process of intensive anthropogenic impact. Their structure, composition, and functioning mode changed physical and chemical properties of urbanozems. It is worth noting that the soils in Moscow are formed artificially with fill up ground in the process of reorganizing parks, boulevards, and other recreational areas. So, the soils in the city are mainly soddy podzolic (55.9\% of all territory), swamp-podzolic (19.2\% of all territory), grey forest ( $8.2 \%$ of all territory). Today urbanozems are the prevalent soils in Moscow. These soils have anthropogenic horizons with high level of heavy metal contamination, incorrect profile structure, inconsistent occurrence of horizons, prevalence of organic substances, construction, and household rubbish.

In recent years, a characteristic decrease in depth of humic soil in the range of 2-4 cm was observed. We showed the possibility of using invertebrates as bioindicators because microarthropods react to changes in the environment sharply.

Our work is aimed at studying the state of the soil in the megapolis and the small settlement, which exist under different man-made burdens. To achieve this aim, we evaluated the numerical strength of soil micro- and mesofauna.

We studied the soils (2013-2015) in different territories of Moscow (along the Moscow ring highway, park belt of «Losiny ostrov» national park) and the small settlement (Bolshoye Dumchino village), which were constantly exposed to the various man-made burdens (highway and transportation complex and emissions from industrial enterprises; dump slag of aluminum casting, respectively). Soil samples were gathered in June (2013-2015) during the dry season in order to prevent fluviraption of the potentially toxic metals by rain and floods.
Six study points were selected in Moscow, three of which were at the distance of 5,50, and $300 \mathrm{~m}$ from the Moscow ring highway. Each soil sample was drawn from five subsamples $(0-20 \mathrm{~cm})$ using palette-knife and mixing samples by sifting through $2 \mathrm{~mm}$ nylon net. The soil was dried by air and stored in polyethylene bags for further research. Soddy podzolic soil (Umbric Albeluvisols) park belt of «Losiny ostrov» (natural area of preferential protection) was used as a background (control). Points in the small settlement (light gray forest soil) were selected at the distance of 20 and $300 \mathrm{~m}$ from the source in contamination (dump slag). Soil samples in the megapolis and small settlement research points were gathered from the top $0-20 \mathrm{~cm}$ of humic-eluvial horizon. Soil samples were taken to the laboratory and stored at $4-5{ }^{\circ} \mathrm{C}$ until used in the analysis. Search for toxic metals was conducted using atomic absorption spectrometer (PG990 model). Precision specified under double measurements was $\pm 5 \%$ for all the selected metals. In order to evaluate potential danger of contaminating soil with toxic metals based on soil samples we determined the sum of concentration coefficient $(\mathrm{Zc})$ for the studied toxic metals.

Counting of different groups of microorganisms was performed by plating soil suspension on solid medium: meatand-peptone agar (MPA, ammonifier), starch-and-ammonia agar (SAA, bacteria and actinomycetes, using mineral nitrogen), Czapek's medium (microfungus) on Getchinson medium (cellulose-decomposing microorganisms). Desorption of microorganisms from soil particles was performed by grinding soil lot with water. Soil suspension in water was shaken (nutator, $15 \mathrm{~min}$ ) and a series of dilutions was prepared. Inoculation on nutriculture medium was repeated five times. After incubation of platings, we counted colony-forming units (CFU) of the microorganisms. Mineralization rate of the soil's organic substance was calculated as relation of the number of bacteria grown on SAA to the number of bacteria on CFU. The number of microorganisms (CFU/g) was calculated per one gram of dry soil.

For calculating microarthropode (representatives of microfauna) in gray forest soil (at the distance of 20 and 300 $\mathrm{m}$ from the source of contamination), we selected twelve soil samples $\left(5 \mathrm{~cm}^{3}\right.$ in volume each) from $0-5 \mathrm{~cm}$ and $5-10 \mathrm{~cm}$ layers over an area of 10 to $100 \mathrm{~cm}^{2}$. The samples were elected in Tullgren funnel. The number and standing population of earthworms in gray forest soil (distance 20 and $300 \mathrm{~m}$ ) were determined using the method of soil digging $(0-20 \mathrm{~cm} \mathrm{dig-}$ ging) over an area of $1 \mathrm{~m}^{2}$. We used linear regression analysis in order to decrease the size and possible sampling errors, and show correlation between the contents of heavy metals in the soil and microorganisms. We also performed analysis using Statistica statistical software.

\section{Results and discussion}

The investigated humic horizons-urbanozems and light-gray forest soil at $20 \mathrm{~m}$ distance from slag-are characterized as highly humous, unlike low humous background soddy podzolic soil with humus content of $1.27 \%$ and light-gray forest soil at $300 \mathrm{~m}$ distance from the slag dump. All the investigated urbanozems are neutral environment compared with background soddy podzolic soil and light-gray forest soil near the 
Table 1. Chemical properties of investigated soils $(0-20 \mathrm{~cm})$ in the megapolis and small settlement under man-made burden.

\begin{tabular}{|l|c|c|c|c|c|}
\hline $\begin{array}{l}\text { Point of } \\
\text { investigation } \\
\text { number }\end{array}$ & $\begin{array}{l}\text { Distance from sources } \\
\text { of contamination, } \mathbf{m}\end{array}$ & Humus, \% & $\mathbf{p H}_{\mathrm{KCL}}$ & $\begin{array}{l}\text { Cation exchange } \\
\text { capacity (CAC), } \\
\text { mmol/(eq)/100 } \mathbf{g}\end{array}$ & $\begin{array}{l}\text { Degree of Saturation of } \\
\text { Soils with Bases, \% }\end{array}$ \\
\hline \multicolumn{7}{|c|}{ Moscow (urbanozem, soddy podzolic soil (background) } \\
\hline $\mathbf{1}$ & 5 & 2.84 & 6.9 & 10.04 & 96.5 \\
\hline $\mathbf{2}$ & 50 & 3.37 & 6.37 & 14.61 & 91.2 \\
\hline $\mathbf{3}$ & 300 & 3.39 & 7.1 & 9.4 & 95.4 \\
\hline $\mathbf{4}$ & Background soil & 1.27 & 4.75 & 12.0 & 26.3 \\
\hline $\mathbf{5}$ & Bolshoye Dumchino village (anthropogenically affected light-gray forest soil) \\
\hline $\mathbf{6}$ & 20 & 2.8 & 4.5 & 6.6 & 45.5 \\
\hline
\end{tabular}

slag dump (Table 1).

The studied urban soils are characterized by high degree of saturation with bases, $91.2-96.5 \%$, compared with very low saturation with the bases of soddy podzolic soil humus horizon. It is noteworthy that slag dump impact on the small settlement's light-gray forest soil causes significant decrease in saturation with bases and forms strongly acid environment. As distance from the slag dump increases, saturation with bases also rises to $88.7 \%$ but soil acidity goes down to $\mathrm{pH}_{\mathrm{KCL}} 5.4$.

\section{Soil microorganisms}

The total number of microorganisms in test points at different distances from the Moscow loop highway varied between $3.58 \times 10^{7}$ and $5.71 \times 10^{7} \mathrm{CFU} / \mathrm{g}$. It was found that the number of ammonifying bacteria in the investigated urbanozems varied between 1.49 and $2.80 \times 10^{7} \mathrm{CFU} / \mathrm{g}$ of the absolutely dry soil. At the same time, the number of bacteria of this group at larger distances from the highway was 2 times higher than in the immediate vicinity of the Moscow loop highway (5 $\mathrm{m})$. At the test point $50 \mathrm{~m}$ from the Moscow loop highway, the number of ammonifying bacteria grew almost 1.5 times and reached $2.26 \times 10^{7} \mathrm{CFU} / \mathrm{g}$. Similar picture exists for aminoautotrophic group. The total number of aminoautotrophs in urbanozems in immediate vicinity from the Moscow loop highway reached $2.05 \times 10^{7} \mathrm{CFU} / \mathrm{g}$.

As sampling distances from the highway increase to 50 $\mathrm{m}$, the number of aminoautotrophs grew to $2.60 \times 10^{7} \mathrm{CFU} / \mathrm{g}$. The highest number of aminoautotrophs in urbanozems was found at the distance of $300 \mathrm{~m}$ from the highway and reached $2.85 \times 10^{7} \mathrm{CFU} / \mathrm{g}$ of the absolutely dry soil. The maximum number of aminoautotrophic bacteria was found in urbanozems at $50 \mathrm{~m}$ distance from the highway $\left(2.26 \times 10^{7} \mathrm{CFU} / \mathrm{g}\right)$. The smallest numbers of bacteria of this group was found in the test point in the immediate vicinity of the highway $1.13 \times 10^{7} \mathrm{CFU} / \mathrm{g}$.

There are interesting results concerning changes in the number of actinomycetes in the physiological aminoautotrophic group. The greatest number of actinomycetes was found in the samples collected in the third point at the distance of up to $300 \mathrm{~m}$ from the Moscow loop highway$0.98 \times 10^{7} \mathrm{CFU} / \mathrm{g}$.
The smallest number of actinomycetes was found in urbanozems at $50 \mathrm{~m}$ distance from the Moscow loop highway.

Numerical strength of fungal flora varied depending on the distance from the source of contamination - the highway; the highest number of colony forming units of fungal flora was found at the greatest distance from the highway $-4.91 \times 10^{5} \mathrm{CFU} / \mathrm{g}$. The number of cellulose decomposing microorganisms was the lowest in the immediate vicinity of the highway $-1.1 \times 10^{5} \mathrm{CFU} / \mathrm{g}$, which was almost 5 times lower than the count of fungal flora in urbanozems most distant from the highway. The number of actinomycetes varied from $1.3 \times 10^{5} \mathrm{CFU} / \mathrm{g}$ in the immediate vicinity of the highway to $2.41 \times 10^{5} \mathrm{CFU} / \mathrm{g}$ at the greatest distance from the highway. The number of actinomycetes in the soils at the test point $50 \mathrm{~m}$ away from the highway dropped drastically. It was 2.5 times lower than the number of cellulose decomposing actinomycetes in urbanozems most distant from the highway (Table 2).

Table 2 shows that not only the total number of microorganisms but also the proportion of different ecology trophic groups changes in the humus horizon of the background soil. For example, the number of ammonifiers, aminoautotrophs, actinomycetes, and also the number of bacteria using mineral nitrogen forms on SAA is lower than the respective numbers of urbanozems.

The total number of soil microorganisms at $20 \mathrm{~m}$ distance from the dump reached $0.72 \times 10^{7} \mathrm{CFU} / \mathrm{g}$; at $300 \mathrm{~m}$ distance rose almost 2 times and reached $1.4 \times 10^{7} \mathrm{CFU} / \mathrm{g}$. It is worth noting that the total number of microorganisms in gray forest soil (20 and $300 \mathrm{~m}$ ) was almost 4.9 and 2.9 times lower, respectively, than values for urbanozem in the city of Moscow.

It was also found that the number of ammonifiers and aminoautotrophs in the soil at the distance of $300 \mathrm{~m}$ from the slag dump rose almost 2-2.5 times compared with the values at $20 \mathrm{~m}$ distance. Those values were recorded for megapolis urbanozems too. At $300 \mathrm{~m}$ distance from the dump, the number of denitrifying bacteria and aminoautotrophs rose to $1.29 \times 10^{7} \mathrm{CFU} / \mathrm{g}$, which was 2.5 times higher compared with respective figures near the slag dump. It is worth noting that the low number of denitrifiers in the megapolis urbanozem and in the faulted lightgray forest soil is due to the lack of mineral nitrogen and weak enrichment of the soil with humus, respectively.

Mineralization rate tended to rise along with increase of anthropogenic burden on the soil. It was 2.39 units near the slag dump and 2.91 units at the larger distance. 
Table 2. Microbiological activity anthropogenically modified urbanozems near the Moscow loop highway and light-gray forest soil in Bolshoye Dumchino village.

\begin{tabular}{|c|c|c|c|c|c|c|c|c|c|}
\hline \multirow{5}{*}{ Distance, m } & \multicolumn{8}{|c|}{ Number of microorganisms } & \multirow{5}{*}{$\mathbf{K}_{\min }^{*}$} \\
\hline & \multirow{4}{*}{ MPA } & \multicolumn{3}{|c|}{$10^{7} \mathrm{CFU} / \mathrm{g}$} & \multicolumn{3}{|c|}{$10^{5} \mathrm{CFU} / \mathrm{g}$} & \multirow{4}{*}{$\begin{array}{c}10^{7} \mathrm{CFU} / \mathrm{g} \\
\text { total } \\
\text { amount }\end{array}$} & \\
\hline & & \multirow[b]{3}{*}{$\begin{array}{c}\text { total } \\
\text { amount }\end{array}$} & \multicolumn{2}{|l|}{ SAA } & \multicolumn{2}{|c|}{$\begin{array}{c}\text { Cellulose-decomposing on } \\
\text { Getchinson medium }\end{array}$} & \multirow{3}{*}{$\begin{array}{c}\text { Fungus on } \\
\text { Czapek's } \\
\text { medium }\end{array}$} & & \\
\hline & & & am & ng them & \multirow[b]{2}{*}{$\begin{array}{c}\text { total } \\
\text { amount }\end{array}$} & \multirow[b]{2}{*}{$\begin{array}{l}\text { among them } \\
\text { actinomycetes }\end{array}$} & & & \\
\hline & & & bacteria & actinomycetes & & & & & \\
\hline \multicolumn{10}{|c|}{ Moscow loop highway } \\
\hline 5 & $\begin{array}{r}1.49 \\
\pm 0.02\end{array}$ & $\begin{array}{r}\underline{2.05} \\
\pm 0.01\end{array}$ & $\begin{array}{r}1.13 \\
\pm 0.02\end{array}$ & $\begin{array}{l}\underline{0.92} \\
\pm 0.06\end{array}$ & $\begin{array}{r}1.33 \\
\pm 0.07\end{array}$ & $\begin{array}{r}1.31 \\
\pm 0.04\end{array}$ & $\begin{array}{r}1.12 \\
\pm 0.02\end{array}$ & 3.58 & 1.38 \\
\hline 50 & $\begin{array}{r}2.26 \\
\pm 0.07\end{array}$ & $\begin{array}{c}2.60 \\
\pm 0.09\end{array}$ & $\begin{array}{r}2.26 \\
\pm 0.03\end{array}$ & $\begin{array}{r}\underline{0.33} \\
\pm 0.20\end{array}$ & $\begin{array}{c}\underline{0.94} \\
\pm 0.05\end{array}$ & $\begin{array}{r}\underline{0.90} \\
\pm 0.04\end{array}$ & $\frac{0.55}{ \pm 0.06}$ & 4.88 & 1.15 \\
\hline 300 & $\begin{array}{r}2.80 \\
\pm 0.19\end{array}$ & $\begin{array}{r}2.85 \\
\pm 0.11\end{array}$ & $\begin{array}{r}1.87 \\
\pm 0.34\end{array}$ & $\begin{array}{r}\underline{0.98} \\
\pm 0.03\end{array}$ & $\begin{array}{r}\frac{2.42}{ \pm 0.06} \\
\end{array}$ & $\frac{2.41}{ \pm 0.10}$ & $\begin{array}{r}\underline{4.91} \\
\pm 0.43\end{array}$ & 5.72 & 1.02 \\
\hline $\begin{array}{l}\text { Background } \\
\text { (reference soil) }\end{array}$ & $\begin{array}{r}\underline{0.93} \\
\pm 0.02\end{array}$ & $\frac{1.09}{ \pm 0.01}$ & $\frac{0.81}{ \pm 0.03}$ & $\frac{0.29}{ \pm 0.05}$ & $\begin{array}{r}\underline{0.12} \\
\pm 0.01\end{array}$ & $\begin{array}{r}\underline{0.09} \\
\pm 0.02\end{array}$ & $\frac{3.12}{ \pm 0.02}$ & 2.06 & 1.17 \\
\hline \multicolumn{10}{|c|}{ Bolshoye Dumchino village } \\
\hline 20 & $\begin{array}{r}0.21 \\
\pm 0.02\end{array}$ & $\begin{array}{r}0.50 \\
\pm 0.03\end{array}$ & $\frac{0.39}{ \pm 0.07}$ & $\begin{array}{r}\underline{0.12} \\
\pm 0.01\end{array}$ & $\begin{array}{r}0.28 \\
\pm 0.02 \\
\end{array}$ & $\begin{array}{r}0.25 \\
\pm 0.03\end{array}$ & 0.05 & 0.72 & 2.39 \\
\hline 300 & $\begin{array}{r}\underline{0.44} \\
\pm 0.01\end{array}$ & $\begin{array}{r}1.29 \\
\pm 0.01\end{array}$ & $\begin{array}{r}1.03 \\
\pm 0.03\end{array}$ & $\begin{array}{r}0.26 \\
\pm 0.01\end{array}$ & $\begin{array}{r}1.6 \\
+0.06\end{array}$ & $\begin{array}{r}1.55 \\
\pm 0.04\end{array}$ & 0.11 & 1.4 & 2.91 \\
\hline
\end{tabular}

${ }^{\star}$ Note: $K_{\min }-$ mineralization rate.

Along with changes in the number of microorganisms, we noted qualitative differences in the composition of physiological trophic groups of the investigated microorganisms. The number of ammonifying microorganisms in the soil grew 2 times at $300 \mathrm{~m}$ distance from the slag dump compared with the immediate vicinity of the slag dump. The low level of microorganisms using organic forms of nitrogen in the immediate vicinity of the slag dump is caused by low soil humus content. The number of microorganisms using mineral forms of nitrogen significantly exceeds the total number of microorganisms using the organic forms of nitrogen in the immediate vicinity of the slag dump. The percent of bacteria in the total group of ammonifiers reached $77-80 \%$ in the immediate vicinity of the slag dump, while the percent of actinomycetes was only $20-23 \%$.

It was found that $\mathrm{Pb}(200 \mathrm{mg} / \mathrm{kg}), \mathrm{Zn}(500 \mathrm{mg} / \mathrm{kg})$, and Cd $(5 \mathrm{mg} / \mathrm{kg})$ content in the soil lead to lowering of activity of dehydrogenase and invertase. Their total inactivation occurred after twofold increase in the above concentrations.

Our studies showed that the activity of protease, catalase, invertase, and urease in the soil contaminated with heavy metals decreased by $41,64,54$, and $53 \%$, respectively, compared with the uncontaminated soil.

So it was shown that the elevated concentration of contaminating substances near highways, including temperature changes in those places, lead to lowering of proteolytic, ureasic, catalasic, and invertasic activities of the soil. The most «sensitive» ferments for chemical toxicants impact were catalase (reductive-oxidative), urease (hydrolytic, nitrogenous metabolism), and invertase.
We found that changes in the total number of microorganisms and the value of mineralization rate in the investigated urbanozems and light-gray forest soils depended on heavy metal contamination level. Soil heavy metal contamination is evaluated as a relation of the actual contaminator content in the soil to the amount of the background content (Table 3 ).

The study showed that the changes in the value of aggregate accrual factor of the investigated heavy metals- $\mathrm{Cd}, \mathrm{Pb}$, $\mathrm{Zn}, \mathrm{Cu}, \mathrm{Cr}$, Ni both in total and mobile forms in urbanozems and light-gray forest soils-caused appropriate changes in the total number of microorganisms and mineralization rate reflecting relation of bacteria grown on SAA to bacteria growing on MPA.

High level of mobility compared with original total content of heavy metals: $\mathrm{Cd}-45-60 \%, \mathrm{Zn}-2.8-29.7 \%, \mathrm{~Pb}-6.9-$ $14.5 \%$, significantly impacted the changes in microbiota of the investigated urbanozems. High level of mobility of heavy metals significantly influences the changes in microbiota of the investigated urbanozems. The number of microorganisms in the investigated soils in the near vicinity of the highway dropped by $37.4 \%$, and in the soils at $50 \mathrm{~m}$ distance from the highway, the number of microorganisms decreased by $14.1 \%$. Impact of the slag dump on the number of microorganisms in the humus layer of light-gray forest soil was evident in the increase in the total number of microorganisms at the greater distance between the investigated object and the source of contamination. So, at the high aggregate accrual factor of heavy metals' (total content) value (43.1 at $20 \mathrm{~m}$ and 5.4 at $300 \mathrm{~m}$ ) and their mobile forms (9.6 at $20 \mathrm{~m}$ and 6.1 at $300 \mathrm{~m}$ ) in anthropogenically modified light-gray forest soil on the test 
Table 3. Dependence of microorganisms on the presence of heavy metals.

\begin{tabular}{|c|c|c|c|c|c|c|c|c|c|c|}
\hline \multirow{3}{*}{$\begin{array}{c}\text { Distance from } \\
\text { sources } \\
\text { of contamination, } \\
\mathbf{m}\end{array}$} & \multicolumn{2}{|c|}{$\begin{array}{l}\text { Aggregate accrual } \\
\text { factor of heavy } \\
\text { metals } \mathrm{Zc}, \mathrm{mg} / \mathrm{kg}\end{array}$} & \multicolumn{6}{|c|}{ Mobility of heavy metals, \% } & \multirow{3}{*}{$\begin{array}{c}\text { Total count of } \\
\text { microorganisms, } \\
10^{7} \mathrm{CFU} / \mathrm{g}\end{array}$} & \multirow{3}{*}{$\mathbf{K}_{\min }$} \\
\hline & \multirow{2}{*}{$\begin{array}{l}\text { total } \\
\text { form }\end{array}$} & \multirow{2}{*}{$\begin{array}{l}\text { mobile } \\
\text { form }\end{array}$} & & & & & & & & \\
\hline & & & Cd & $\mathbf{P b}$ & $\mathrm{Zn}$ & $\mathrm{Cu}$ & $\mathrm{Cr}$ & $\mathrm{Ni}$ & & \\
\hline \multicolumn{11}{|c|}{ Moscow (Moscow loop highway, urbanozem) } \\
\hline 5 & 7.8 & 4.5 & 56.5 & 9.1 & 20.6 & 5.3 & 5.3 & 7.5 & 3.6 & 1.4 \\
\hline 50 & 4.3 & 2.8 & 50.0 & 14.5 & 29.7 & 9.4 & 9.4 & 5.1 & 4.9 & 1.2 \\
\hline 300 & 7.0 & 5.1 & 60.0 & 10.2 & 23.9 & 9.0 & 9.0 & 9.4 & 5.7 & 1.0 \\
\hline $\begin{array}{l}\text { Background } \\
\text { (control soil) }\end{array}$ & 1.0 & 1.0 & 50.0 & 8.2 & 21.7 & 11.2 & 16.8 & 13.2 & 2.1 & 1.2 \\
\hline \multicolumn{11}{|c|}{ Bolshoye Dumchino village (slag dump, light-gray forest soil) } \\
\hline 20 & 43.1 & 9.6 & 45.3 & 6.9 & 2.8 & 1.8 & 1.5 & 5.5 & 0.7 & 2.4 \\
\hline 300 & 5.4 & 6.1 & 46.0 & 7.4 & 3.2 & 2.9 & 1.0 & 7.6 & 1.4 & 2.9 \\
\hline
\end{tabular}

${ }^{\star}$ Note: $K_{\min }-$ mineralization rate.

Table 4. Species composition and the number of microarthropods in light-gray forest middle loamy soil at different distances from the slag dump.

\begin{tabular}{|l|c|c|}
\hline \multirow{2}{*}{ Goup } & \multicolumn{2}{|c|}{ Specimen/m ${ }^{\mathbf{2}}$} \\
\cline { 2 - 3 } & $\mathbf{1 5 0} \mathbf{~ m}$ & $\mathbf{4 5 0} \mathbf{~ m}$ \\
\hline Collembolans (Collembola Lubbock): & 1440 & 4644 \\
H. manubralis & $542 \pm 52$ & $1382 \pm 140$ \\
Jsotoma habitas & - & $1246 \pm 122$ \\
Pseudosinella alba & - & 6496 \\
\hline Ticks (Acari) & 2131 & $3990 \pm 378$ \\
\hline Oribatid mites (Oribatida): & $1744 \pm 172$ & - \\
Tectocepheus velatus & $542 \pm 52$ & $3354 \pm 331$ \\
Cosmochthonius lanatus & $400 \pm 41$ & 248 \\
Puethoribates punctum & $542 \pm 52$ & $154 \pm 16$ \\
\hline Gamasid mites (Gamasoidea): & 99 & 1746 \\
Arcthoseus cetratus & - & - \\
\hline Astigmata mites (Astigmata): & 155 & $1661 \pm 159$ \\
Tyrophagus perniciosus & $61 \pm 7$ & 482 \\
\hline Gyppopus sp. & - & \\
\hline Trombidiform mites: Trombidipormes sp. & 33 & \\
\hline
\end{tabular}

Table 5. Species composition and numerical strength of macrofauna in light-gray forest middle loamy soil.

\begin{tabular}{|l|c|c|}
\hline \multirow{2}{*}{ Species composition and the number of macrofauna, specimen $/ \mathbf{m}^{\mathbf{2}}$} & \multicolumn{2}{|c|}{ Distance, $\mathbf{m}$} \\
\cline { 2 - 3 } & $\mathbf{1 5 0}$ & $\mathbf{4 5 0}$ \\
\hline Large reddish worm (Lumbricus terrestris Linnaeus) & 0 & $0.3 \pm 0,2$ \\
\hline Allolobophora caligonosa earthworm (Lumbricidae) & $22 \pm 3$ & $57 \pm 8$ \\
\hline Small reddish worm (Lumbricus rubellus Hoffmeister) & 0 & $0.6 \pm 0,2$ \\
\hline Young worms & $8 \pm 2$ & $1,3 \pm 0,6$ \\
\hline Invertebrate larvae & $4 \pm 1$ & $5 \pm 1$ \\
\hline Total number of specimen & $34 \pm 6$ & $64.2 \pm 10$ \\
\hline
\end{tabular}


plot near $(20 \mathrm{~m})$ slag dump the number of microorganisms was $0.7 \times 10^{7} \mathrm{CFU} / \mathrm{g}$. It grew 2.4 times to $1.4 \times 10^{7} \mathrm{CFU} / \mathrm{g}$ in the anthropogenically modified light-gray forest soil on the test plot at greater distance $(300 \mathrm{~m})$ from the dump.

One of the indicators for the evaluation of soil contamination is a species composition of soil invertebrates (Table 4).

According to the data in Table 4, it is possible to infer that the number and species composition of microarthropods are indicators of intensity of heavy metal soil contamination. The total number of large pedobionts for which the soil is a solid medium, under perennial grasses was $33.6 \pm 4.9$ specimen in one sample. Their population consists of three groups of large soil animals (Table 5).

Lumbricidae (earthworms) are prevalent at $150 \mathrm{~m}$ distance from the slag dump. Juvenile young forms represented $26.6 \%$ of the population. Allolobophora caligonosa worm was the most numerous in the earthworm group $-73.9 \%$.

The total numerical strength of macrofauna on the territory at $450 \mathrm{~m}$ distance from the slag dump, compared with the territory in the immediate vicinity, was 2.5 times greater. The numerical strength and the number of species of Lumbricidae was also higher. Among invertebrates, as in the first study, earthworms were prevalent (99\%). In the Lumbricidae group, Allolobophora caligonosa earthworm was manifestly prevalent $-96.7 \%$. Large reddish worm had $0.5 \%$, small reddish worm $-1.06 \%$. Macrofauna representatives are unevenly distributed in the soil profile. The top $10 \mathrm{~cm}$ layer of the soil is the most populous. The numerous strength of most other species decreased with depth and like in the case of Allolobophora caligonosa earthworm - slightly varied with depth (about 1 specimen for 1 sample). Total numerical strength near the slag dump was 2.5 times lower than on the plot at 450 $\mathrm{m}$ distance. As it is known, longtime human impact leads to spatial nonuniformity in biotopes: it grows at lesser distances from the source of contamination because of emerging micro plots unfit for habitation.

Reduced aggregation of the total mesofauna biomass in the vicinity of the slag dump is due to veritable drop of this measure for most invertebrate species.

Results of the study show that microbiota structure changes both in Moscow soils and soils under slag dump impact. Despite local differences between the test plots, there is a tendency towards lower mineralization rates at greater distances between the test object and the source of contamination. The mineralization rate for soils near the slag dump was 1.9 units. It dropped to 1.5 units with increase in distance from the dump to $300 \mathrm{~m}$.

\section{Conclusion}

This study investigated the total concentration of toxic heavy metals in the topsoil of urbanozems (city of Moscow) and gray forest soils (Bolshoye Dumchino village). It was found that the average concentrations of the investigated heavy metals exceeded the corresponding base levels. Studying spatial variations of heavy metal content in soils, we showed that positive dynamics of the heavy metal content in soils was tied with road traffic, increasing urbanization, accrual of slag waste.

The studies proved that the source of contamination significantly influences the species composition and numerical strength of microarthropodes in $0-20 \mathrm{~cm}$ layer of light-gray forest middle loamy soil.

It was proven that increased intensity of heavy metal accrual lead to appropriate decrease in overall numerical strength of microbiota and increase in mineralization rate in both urbanozems and light-gray forest anthropogenically modified soil.

\section{References}

Abera, W. \& Assen M. (2019) Dynamics of selected soil quality indicators in response to land use/cover and elevation variations in Wanka Watershed, Northwestern Ethiopian highlands. Ekológia (Bratislava), 38(2), 126-139. DOI: 10.2478/eko-2019-0010.

Arinushkina, E.V. (1970). Rukovodstvo po khimicheskomu analizu pochv. Moscow: Moscow State University Publishing House.

Arkharov, I.A., Simakova, E.N. \& Navasardyan E.S. (2016). Landfill gas as feedstock for energy and industrial processes. Chemical and Petroleum Engineering, 52(7-8), 547-551. DOI: 10.1007/s10556-016-0229-y.

Bednova, O.V., Kuznetsov, V.A. \& Tarasova N.P. (2018). Eutrophication of an urban forest ecosystem: Causes and effects. Doklady Earth Sciences, 47(1), 124-128. DOI: 10.7868/S0869565218030210.

Falt’an, V., Krajčírovičová, L., Petrovič, F. \& Khun M. (2017). Detailed geoecological research of terroir with the focus on georelief and soil-a case study of Krátke Kesy vineyards. Ekológia (Bratislava), 36(3), 214-225. DOI: 10.1515/eko-2017-0018.

Fritz, S., See, L., Perger, C., McCallum, I., Schill, C., Schepaschenko, D., Duerauer, M., Karner, M., Dresel, C., Laso-Bayas, J.C., Lesiv, M., Moorthy, I., Salk, C.F., Danylo, O., Sturn, T., Albrecht, F., You, L., Kraxner, F. \& Obersteiner M. (2017). A global dataset of crowdsourced land cover and land use reference data. Scientific Data, 4, 170075. DOI: 10.1038/sdata.2017.75.

Kozodaev A., Andrushko, A. \& Firsova A. (2019a). Research of reagentfree waste water treatment methods of the chrome plating line for mineralizing the rod of hydraulic cylinders. IOP Conference Series: Materials Science and Engineering, 492, 012021. DOI: 10.1088/1757899X/492/1/012021.

Kozodaev A., Korpusova, Y. \& Shulzhenko A. (2019b). Waste water depuration of the manufacture of mirrored surfaces for energy saving. IOP Conference Series: Materials Science and Engineering, 492, 012020. DOI: 10.1088/1757-899X/492/1/012020.

Ksenofontov, B.S. \& Goncharenko E.E. (2016). Intensification of purification of surface sewage by use a bioflocculant. Herald of the Bauman Moscow State Technical University, Series Natural Sciences, 66(3), 118-127. DOI: 10.18698/1812-3368-2016-3-118-127.

Ksenofontov, B.S. \& Starostin I.I. (2016). Use of guiding devices for aeration and dust suppression intensification in quarries using activated water. Ecology and Industry of Russia, 20(7), 10-12. DOI: 10.18412/1816-03952016-7-10-12.

Ksenofontov, B.S., Kozodaev, A.S. \& Taranov R.A. (2016). The problems of rare earth metals extraction from coal ash in the form of solvents and its concentrating. Ecology and Industry of Russia, 20(4), 12-15. DOI: 10.18412/1816-0395-2016-4-12-15.

Ksenofontov, B.S., Butorova, I.A., Kozodaev, A.S., Afonin, A.V. \& Taranov R.A. (2017). Problems of toxicity of ash and slag waste. Ecology and Industry of Russia, 21(2), 4-9. DOI: 10.18412/1816-0395-2017-2-4-9.

Ksenofontov, B.S. (2018). Engineering problems of wastewater sludge dewatering. Ecology and Industry of Russia, 22(9), 4-7. DOI: 10.18412/18160395-2018-9-4-7.

Ksenofontov, B.S. \& Goncharenko E.E. (2018). The use of activated sludge after preliminary flotation treatment as a bioflocculant. Ecology and Industry of Russia, 22(3),10-14. DOI: 10.18412/1816-0395-2018-3-10-14.

Ksenofontov, B.S. (2019) Simulation of wastewater treatment in flotation machine. AIP Conference Proceedings, 2195(1), 020070. DOI: 10.1063/1.5140170.

Kuznetsova, A.I., Lukina, N.V., Tikhonova, E.V., Gornov, A.V., Gornova, M.V., Smirnov, V.E., Geraskina, A.P., Shevchenko, N.E., Tebenkova, D.N. \& Chumachenko S.I. (2019). Carbon stock in sandy and loamy soils of coniferous-broadleaved forests at different succession stages. Eurasian Soil Science, 52(7), 756-768. DOI: 10.1134/S1064229319070081. 
Novák, J., Jankowski, K., Sosnowski, J., Malinowska, E. \& WiśniewskaKadżajan B. (2020). Influence of plant species and grasslands quality on sequestration of soil organic carbon. Ekológia (Bratislava), 39(3), 289-300. DOI: 10.2478/eko-2020-0023.

Pershin, D., Chernykh, D., Biryukov, R. \& Zolotov D. (2020). Influence of landscape diversity on temporal variability of ecosystem functioning in the south of Western Siberia Ekológia (Bratislava), 39(3), 270-276. DOI 10.2478/eko-2020-0021.

Petlušová, V., Petluš, P., Tobiašová, E. \& Hreško J. (2020). Using the methodological procedures for water erosion risk areas identification for sustainable land use. Ekológia (Bratislava), 39(2), 145-158. DOI: 10.2478/ eko-2020-0011.

Stepanova, L.P. \& Pisareva A.V. (2019). Effect of production waste on the ecological condition of gray forest soils. International Multidisciplinary Scientific GeoConference Surveying Geology and Mining Ecology Management, 19(5.2), 315-322. DOI: 10.5593/sgem2019/5.2/S20.039.

Stepanova, L.P., Pisareva, A.V. \& Raskatov V.A. (2019a). Microflora transformation as a result of the influence of pollutants on the top layer of soil. International Multidisciplinary Scientific GeoConference Surveying Geology and Mining Ecology Management, 19(4.2), 99-106. DOI: 10.5593/ sgem2019V/4.2/S04.014.
Stepanova, L.P., Yakovleva, E.V. \& Pisareva A.V. (2019b). Spatio-temporal dynamics of soil geochemical anomalies in the zone of impact of slag residuals. Ecology and Industry of Russia, 23(3), 44-48. DOI: 10.18412/18160395-2019-3-44-48.

Stepanova, L.P., Pisareva, A.V., Nechushkin, Yu.V. \& Myshkin A.I. (2019c) Dependence of health conditions of population on the level of environment Pollution. IOP Conference Series: Earth and Environmental Science, 350, 012043. DOI: 10.1088/1755-1315/350/1/012043.

Stepanova, L.P., Pisareva, A.V. \& Tsikanavichute V.E. (2020a). Environmental assessment of the toxic effect of slagheap on soil continuum. IOP Conference Series: Earth and Environmental Science, 459(3), 032045. DOI: 10.1088/1755-1315/459/3/032045.

Stepanova, L.P., Pisareva, A.V. \& Tsikanavichute V.E. (2020b) Toxicological assessment of the impact of metallurgical industry waste on the environmental properties of light gray forest soils. Ecology and Industry of Russia, 24(6), 54-59. DOI: 10.18412/1816-0395-2020-6-54-59.

Trifonova, T.A. \& Shirkin L.A. (2015). The analysis of cumulative influence of factors of environment on a state of health of the population of Vladimir region. Global Journal of Health Science, 7(3), 309-316. DOI: 10.5539/ gihs.v7n3p309. 